\title{
TECHNOLOGY OF PRODUCTION AND PROCESSING OF PEAT AT ENTERPRISES OF THE RIVNE REGION
}

\author{
Moshynskyi V.S. \\ National University of Water and Environmental Engineering \\ (NUWEE), Professor, Doctor of Sciences (Agricultural), Professor, \\ Department Of Land, Cadaster, Land Monitoring And \\ Geoinformatics, Ukraine \\ Solvar L.M. \\ National University of Water and Environmental Engineering \\ (NUWEE), Senior Lecturer, Institute of Postgraduate Education, \\ Ukraine \\ Semeniuk V.V. \\ National University of Water and Environmental Engineering \\ (NUWEE), Senior Lecturer, \\ Department of Development of Deposits and Mining, Ukraine \\ Kucheruk M.O. \\ National University of Water and Environmental Engineering \\ (NUWEE), Assistant, Department of Development of Deposits and \\ Mining, Ukraine
}

\section{Summary}

This section analyzes the development of Ukraine's peat industry. Attention is drawn directly to the prospects of the peat industry of Volyn, in particular the Rivne region. The technologies of peat extraction and processing at the enterprises of Rivne region are described in detail, their advantages and disadvantages are considered, taking into account losses in the process of development on the example of peat deposits of Rivne region. An alternative path and recommendations for more rational development of industrial reserves of peat deposit with reduced economic costs have been developed.

\section{Introduction}

The peat industry of Ukraine was started in 1919. Until the mid1960s, peat was used as fuel for power plants, sugar and alcohol factories, schools, hospitals, and in part for the general population. With the development of gasification and electrification, peat began to lose its position as an energy resource. But peat briquette factories 
continued to be built, as this type of fuel was extremely popular with non-gas consumers $[1,2]$.

Ukraine's peat deposits are represented mainly by lowland type (96\% of all resources). There are also small (1.8\%), transitional (1.6\%) and mixed $(0.6 \%)$ types of peat deposits. By the nature of peat accumulation and features of peat deposits in the territory of Ukraine, the following peat regions are distinguished: Polissia, Małopoliska, Lisostepova, Stepova, Carpathian. The most favorable conditions for peat accumulation occurred in the post-glacial period in Polissia, where numerous and diverse peat bogs were formed. The peat reserves and resources of this region (Volyn, Rivne, Chernihiv administrative regions) make up almost half of all peat stock of Ukraine [3].

According to geological-geomorphological features, 11 peat-marsh regions are distinguished within the peat-marsh regions, each of which is characterized by a certain degree of wetland and peat land. The most swampy (10.1\%) and peaty $(7.3 \%)$ districts of Western Polissia in the peat-swamp region of Polissia [4].

In Ukraine, most swamps are peat lands. The latter term is often used for drained marshes; sometimes under peat land understand the peat bog, especially when developing it. In the marshes of Ukraine lowland peat deposits prevail, in the Western Polissia and Carpathians mixed transitional types occur. Top and mixed top types of deposits are known in Western and Central Polissia, in the Carpathians. The most widespread peat deposits are in Rivne, Volyn, Chernihiv, Zhytomyr Kyiv, Lviv regions. Tariffs of Rivne and Volyn regions reach 6.5\%, while in Ternopil, Khmelnitsky, Vinnitsa, Cherkasy, Poltava, Sumy and Kharkiv regions it does not exceed $1.9 \%$ of the whole territory. Even less common are peat deposits in Mykolaiv, Zaporizhia, Dnipropetrovsk, Transcarpathian, Ivano-Frankivsk regions, where the degree of peat land does not exceed $0.1 \%$ [4].

The Ukrtorf concern produces up to 600,000 tons of peat annually, the vast majority of which $(62 \%)$ is converted to fuel briquettes - a fairly efficient solid fuel with a lower combustion heat of about $15 \mathrm{MJ} /$ $\mathrm{kg}$, humidity up to $20 \%$ and ash content up to $23 \%$.

About $50 \%$ of Ukraine's peat reserves are concentrated in three oblasts - Volyn, Rivne, and Chernihiv. The geological peat reserves in Ukraine are estimated at 2.2 billion tons. The total area of the fields is about one million hectares, including 0.6 million hectares within 
industrial depth; Balance of peat reserves exceeds 838 million tons. Peat reserves in industrial fields are 22.6 million tons, and the prepared industrial capacity for peat extraction is 2.1 million tons (for the production of peat briquettes - 0.7 million tons).

In general, the largest number of balance reserves is in the Volyn region (165 million tons), which is about $21 \%$ of all industrial deposits of Ukraine, the second place is taken by the Rivne region with reserves over 133 million tons, or $17 \%$ from the national ones (Fig. 1). .

The most promising region for the construction of mining and peat processing enterprises is Polissia. Deposits operated by the Ukrainian Peat Industry Concerns of Ukrtorf concentrate 15\% of explored reserves, $28 \%$ of reserves, prospects for exploration - 18\%, security (those located within protected areas) - 11\%, and drained ones - 17\%, for saline (Ac> 35\%) - 5\%, for small deposits - 6\% [5].

The most reserve and prospecting for peat deposits is in the Rivne region. According to the State Geomology, 2168 peat deposits were discovered and explored in the territory of Ukraine. About 100 thousand hectares of peat lands belong to the objects of the nature reserve fund.

The state concern Ukrtorf is engaged in the extraction and processing of peat in the country, in the structure of which there are the following state enterprises: "Volintorf", "Zhytomyrtorf", "Kyivtorf" (operates in the territory of three oblasts - Kyiv, Poltava and Cherkassy - one peat plant ), Podillatorf (Khmelnytskyi, Vinnytsia and Ternopil region), Rivnetorf (one plant for the production of Smigatorf peat briquettes), Sumy and Irvantsivsky [6].

During the formation of peat deposits, peat deposits, depending on water and mineral nutrition, vegetation, climate and when they change, may undergo certain stages associated with the accumulation of different types of peat. Therefore, in nature there is a great variety of stratigraphic features of peat deposits.

The primary unit of classification is the type of peat [7]. Currently, 150 species of peat have been identified, of which 65 are lowland, 41 are transitional, 44 are upland. All species are grouped into 6 groups woody, herbaceous, mossy, grassy, grassy-mossy, mossy.

These six groups are grouped into three subtypes - forest, forestdrab, and driftwood. And the subtypes form 4 types of peat deposits lowland, upland, transitional and mixed. 
Peat is a layering of peat species, currently there are 90 varieties of peat deposits.

The lowland type of deposits is deposits with soil nutrition, so the content of mineral salts in the peat. Ash content is different: from 1525 , up to $30-40 \%$.

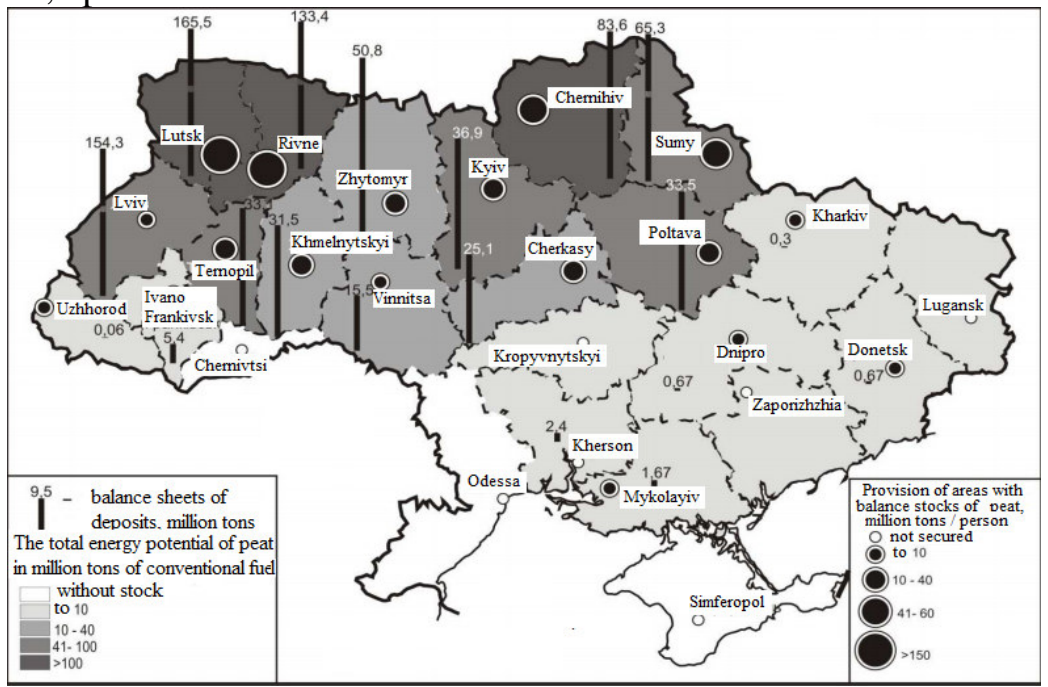

Fig. 1. Distribution of peat resources in the territory of Ukraine

High-ash lowland fields after hydro melioration are more appropriate to use in agriculture as forage or arable land. In its composition lowland peat contains lime and peat vivanite, which promotes high fertility of agricultural crops. Lowland peat with high ash content, carbonate and phosphorus content and naturally low acidity is also a valuable fertilizer or component for the production of plant growth stimulants, soil mixtures for the cultivation of flowers, vegetables, mushrooms, the basis for the manufacture of composts and the like.

Lowland peat deposits include deposits formed wholly or largely from lowland peat.

Horse fields are fed mainly by precipitation, so the peat bogs have low ash content, are rich in bitumen ( 9 to 15\%) and have high acidity. Horse-type peat is used in animal husbandry for litter; for the production of coke, semi-coke, wax, fodder yeast, are important components for the production of light soil mixtures and substrates for 
many types of ornamental, vegetable, flower, seedling, seedling, plant growth stimulants, etc.

Horse-type peat deposits are widespread only in the West Polissia peat area and in the Carpathians. The main stocks of horse peat have been discovered at the deposits of Rivne region [8].

On peat deposits of transitional type of nutrition surface-sewage, so the deposit is composed of different types of peat, the bottom - lowland species, and the lowland floor - the top. Deposits with transitional peat deposits are usually found in small and shallow basins and valleys.

At mixed-type deposits, the deposit is represented by a layer of different types of peat - lowland and transitional, covered by a top, with a capacity of not less than $0.5 \mathrm{~m}$.

Territorial congestion is one of the most important indicators. It characterizes not only the share of peat covered area, but also the relative value of peat reserves that occur and spread, and therefore the relative abundance of peat. And if the price of the territory of Ukraine does not exceed $1.7 \%$, the figure for the Volyn, Rivne and Chernihiv regions is 8.25, respectively; 9.30; and 3.72\%, and in the Polissia districts of these regions and Zhytomyr region it reaches $15 \%$.

Most types of peat found in the territory of Ukraine are suitable for the production of organic fertilizers, mainly peat-based composts, animal bedding, plant growth stimulants, soil mixtures, peat cups for seedlings and more.

Given the limited stock of peat in Ukraine, as well as the situation on the fuel market in our country, we can agree with the statement that the main use of peat in modern conditions is the production of peat fuel (peat briquettes and lump peat) for household consumption. It is necessary to study in more detail the feasibility of introducing small peat-fired power plants, based on the experience of Finland, where about $15 \%$ of electricity is generated by its combustion [9].

Unfortunately, in the presence of such diverse peat raw materials, over $80 \%$ of Ukraine's peat, regardless of its properties, is burned, while in the world more than $80 \%$ of peat is used in agriculture as a source of humus.

The Rivne region ranks second among all regions of Ukraine in terms of the number of peat deposits and reserves (Fig. 2) [10]. With a total area of 20.1 thousand square $\mathrm{km}$, the area of peat deposits within the limits of industrial depth of deposits is 1.33 thousand square $\mathrm{km}$ or 
$6.5 \%$ of the total. The peat fund of the region consists of 332 peat deposits with a total area within the limits of industrial depth of 133.6 thousand hectares and geological reserves of peat 376.9 million tons or $17 \%$ of the total in Ukraine, of which: balance reserves amount to 188.7 million tons, on-balance sheet - 173.2 million tons [11].

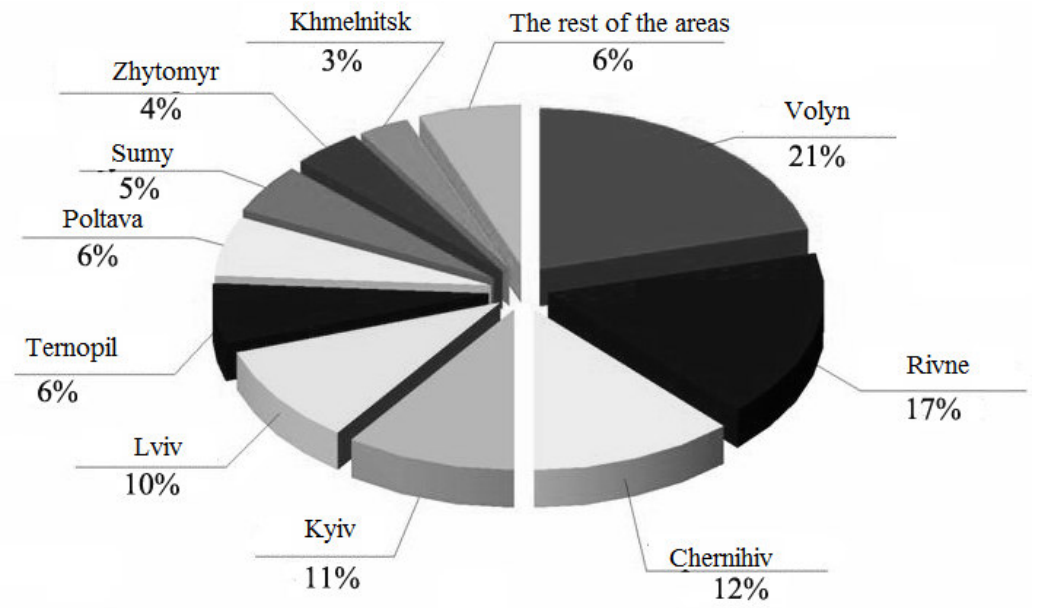

Fig. 2. Distribution of peat reserves by regions of Ukraine

By administrative districts, the distribution of peat reserves and the peat land are uneven. In Rokytne district, peat resources make up 67.3 thousand tons, their area of distribution is 28470 hectares, the territory's congestion is $12.5 \%$; in the Dubrovytskyi district, geological reserves amount to 63066 thousand tonnes, area - 25046 hectares, territorial congestion - $13.5 \%$. In the southern regions, for example, in Radyvylivskyi, the total area of peat deposits is 544 ha, reserves - 2467 thousand tons, and peat land $-0.6 \%$; in Koretskyi, the total area of peat deposits is 141 hectares, the peat reserves are 198 thousand tons, and the territory is $0.1 \%$.

More than $50 \%$ of the discovered and explored peat stock is deposits with an area less than 100 hectares, but the main reserves are concentrated on 49 peat deposits with an area over 500 hectares $[1,10,11]$.

More than $80 \%$ of the peat fund explored is low-lying peat reserves. But at the same time, a considerable share is made of peat deposits of transitional and transitional types, which occur on 25 peat deposits and cover an area of about 15.0 thousand hectares, and reserves of peat type - 
more than 50 million tons. These peat deposits are grouped in northwestern part of the region. The most significant of them are the fields: Morochno I, which has an area within the limits of industrial depth of 5.1 thousand hectares and geological reserves - 15.86 million tons; Morochno II - with an area of 4.7 thousand hectares and geological reserves of 12.6 million tons.

The peat reserves of the region by types of deposits are distributed as follows: lowland $-80 \%$, high $-9.7 \%$, transitional $-6.2 \%$, mixed $-4.1 \%$.

According to the degree of study of peat reserves are divided into exploration categories A, B, C1 and previously explored - categories C2.

The degree of exploration of the peat stock of the region is low. Of the total peat stock of the region, $25 \%$ of the fields have been explored in detail and the reserves have been approved under category A.

The remaining $75 \%$ of the fields have been explored by preliminary and route exploration, as well as surveyed; reserves - approved under categories $\mathrm{C} 1, \mathrm{C} 2$.

The largest peat deposits by area are explored in detail, they have 168.3 million tons of peat reserves, which is $44.8 \%$ of the total reserves of the region.

Peat deposits are spread throughout the region. Their greatest concentration is observed in the northern part of the region, in the valleys of the rivers Styr, Goryn, Sluch, Sviga, and others - in the right tributaries of the Pripyat River, which represent the western part of the Ukrainian Polissia.

For further development, the first three groups of deposits are the most promising: operational, reserve and prospecting for exploration, which are concentrated in 80 deposits (Table 1).

Table 1

Summary table of peat reserves of Rivne region on peat deposits with area over 10 hectares

\begin{tabular}{|c|c|c|c|c|}
\hline \multirow{2}{*}{$\begin{array}{l}\text { The degree of } \\
\text { industrial } \\
\text { development }\end{array}$} & \multirow[b]{2}{*}{$\begin{array}{c}\text { Number of } \\
\text { deposits }\end{array}$} & \multirow{2}{*}{$\begin{array}{l}\text { Area within } \\
\text { industrial } \\
\text { depth, ha }\end{array}$} & \multicolumn{2}{|c|}{ Peat reserves, thousand tons } \\
\hline & & & $\mathrm{A}+\mathrm{B}+\mathrm{C}_{1}+\mathrm{C}_{2}$ & $\begin{array}{c}\text { Off-balance } \\
\text { sheet }\end{array}$ \\
\hline 1. Operating & 46 & 21410 & 61527 & 5588 \\
\hline 2. Backup & 21 & 16324 & 48059 & 3304 \\
\hline $\begin{array}{l}\text { 3. Prospective for } \\
\text { exploration }\end{array}$ & 13 & 16682 & 30900 & 13189 \\
\hline 4. Rest & 252 & 73469 & 47261 & 151315 \\
\hline 4.1. Security & 15 & 29892 & - & 77933 \\
\hline 4.2. Dried & 127 & 19027 & - & 65154 \\
\hline 4.3.For the greens & 16 & 1898 & - & 5761 \\
\hline 4.4. Shallow & 94 & 22652 & 47261 & 2467 \\
\hline Total & 332 & 127885 & 187747 & 173396 \\
\hline
\end{tabular}


The region's peat reserve fund consists mainly of a number of large peat deposits of industrial importance.

Peat mining distinguishes between the following methods of opencast mining: layer-by-surface, layer-by-slot and quarrying.

At present, the layer-by-surface or milling method of extraction is dominant in the region.

In this method, the final production is a milling crumb, characterized by the following indicators: type of deposit; the degree of decomposition of the deposit layer; moisture content; ash content; specific heat of combustion; clogging with wood, scrapes and other extraneous inclusions; bulk density; content of small fraction up to 1 $\mathrm{mm}$; the average diameter of the particles.

Milling peat is used as a raw material for the production of the following products: fuel; fertilizer; litter; pots and packing material; activated carbon; yeast; mountain wax.

When choosing a type of product, the following indicators are taken into account: type of deposit, degree of decomposition (R) and ash content (Ac) (Table 2).

Depending on the type of products they change. When choosing a product type, it should be borne in mind that the characteristics of the deposit vary both in area and capacity [12].

Table 2

Requirements for peat as a raw material for the manufacture of various products [12]

\begin{tabular}{l|l|l|l}
\hline № & \multicolumn{1}{|c|}{ Type of products } & \multicolumn{1}{c}{ Lowland peat } & \multicolumn{1}{c}{$\begin{array}{c}\text { Horse and transitional } \\
\text { peat }\end{array}$} \\
\hline 1 & Fertilizer & $\begin{array}{l}\mathrm{R}-\text { from } 15 \% \\
\mathrm{~A}^{\mathrm{c}}-\text { to } 35 \% \\
\mathrm{CaO}-\text { from } 10 \% \\
\mathrm{P}_{2} \mathrm{O}_{5}-\text { from } 1 \%\end{array}$ & $\begin{array}{l}\mathrm{R}-\text { from } 15 \% \\
\mathrm{~A}^{\mathrm{c}}-\text { from } 35 \%\end{array}$ \\
\hline 2 & Fuel & $\begin{array}{l}\mathrm{R}-10 \% \text { and above } \\
\mathrm{A}^{\mathrm{c}}-\text { to } 35 \%\end{array}$ & $\begin{array}{l}\mathrm{R}-\text { from } 20 \% \\
\mathrm{~A}^{\mathrm{c}}-\text { to } 23 \%\end{array}$ \\
\hline 3 & Mountain wax & $\begin{array}{l}\text { All types of peat } \\
\mathrm{A}^{\mathrm{c}}-\text { to } 10 \%, \mathrm{R}-\text { from } 30 \%, \text { the main criteria are } \\
\text { the content of gasoline bitumen }-5 \%\end{array}$ \\
\hline 4 & Yeast & $\begin{array}{l}\mathrm{R}-\text { from } 35 \% \\
\mathrm{~A}^{\mathrm{c}}-\text { to } 6 \%\end{array}$ \\
\hline 5 & Activated carbon & $\begin{array}{l}\mathrm{R}-\text { from } 35 \% \\
\mathrm{~A}^{\mathrm{c}}-\text { to } 6 \%\end{array}$ \\
\hline 6 & Litter & $\begin{array}{l}\text { All types of peat } \\
\mathrm{R}-\text { from } 15 \%-20 \%, \mathrm{~A}^{\mathrm{c}}-\text { to } 15 \%\end{array}$ \\
\hline 7 & Pots and packing material & $\begin{array}{l}\text { All types of peat } \\
\mathrm{R}-\text { from } 10 \% \text { to } 25 \%, \mathrm{~A}^{\mathrm{c}}-\text { to } 15 \%\end{array}$ \\
\hline
\end{tabular}


Currently in the area of milling peat mainly produce fuels and fertilizers.

Peat production is carried out by the State Enterprise Rivnetorf of the Ukrtorf State Concern of the Ministry of Fuel and Energy of Ukraine.

SE "Rivnetorf" in different years consisted of structural units that worked on the following raw materials bases: "Volodymyretstorf" Gryada; Mokwintorf - Sand; Bereznetorf - Dike Halo; Chemernetorf Korabelskoe; "Smigatorf" - Starniks; "Klesivtorf" - Kreminne, "Verbatorf" - Willow I.

As of 1 January 2020, only the Smigatorf unit, which performs mining operations at the Starniki peat field, remained in the structure of Rivnetorf SE. For all other reasons, all other units are liquidated or are in the process of being liquidated, but in the future the extraction works can be resumed in the listed deposits.

Two types of milling peat are produced at Rivnetorf: fuel and agriculture. From the fuel milling peat produce semi-briquettes, which are used as municipal fuel.

In the milling method of peat extraction, products are obtained in the form of a loose mixture of small particles, different in size, but not more than $20-25 \mathrm{~mm}$. The milling method derives its name from the initial milling operation. Milling - the process of processing peat deposits with mills. The cutter is a tool with cutting elements (knives); milling cutters used in metal and woodworking industries are an example. Rotating around their own axis and sinking into the stock at a progressive stroke, they remove a small thickness of the layer, turning it into a crumb.

In the milling method, the formation of the reservoir is performed from the surface by horizontal layers, so it is also called a layer-bysurface method of development. Drying of the milled crumb is carried out in the same area, where milling was performed in natural open-air conditions due to the use of solar energy and heat of the air masses. This method depends on the weather and is seasonal. In order to accelerate the drying and obtain a more homogeneous moisture content of the finished products is used to stir the drying layer. Dried to the required humidity, the milling peat is collected from the spread of preprepared rolls in the stack of the correct triangular or trapezoidal section. Peat comes into the stack directly from the harvesting machine 
or from the piles at the foot of the stack created by the bunker harvesters. From the heaps to the pile, the peat moves the stacking machine and evens it on the surface with an even layer.

Production of FT is determined by the schemes of storage of finished products. Currently, there are three schemes of assembly of finished products, depending on the location of units of storage of finished products (stacks), they are divided:

I. stacks are placed perpendicular to the map and parallel to the gross channels;

II. stacks are arranged parallel to the card and perpendicular to the gross channels;

III. enlarged stacks are placed on the border or beyond the deposit [13].

According to the first scheme, as a rule, mainly used bunker harvesting machines, which collect the finished product in the hopper and take it to the storage location on the strips. Thus peat is collected directly from the spread - pneumatic, or from the rolls - mechanical method of harvesting.

According to the II scheme, transshipment machines are used, which pour peat from pre-assembled rolls (distance between rolls of $20 \mathrm{~m}$ ) from one roll to another, until the formation of a stack.

The third scheme depends on the production technology and aims to create conditions for export of finished products to the consumer, usually by motor transport. At the same time use loading machines.

Extraction of peat suitable for fertilizer and fuel within the "Maidan" section of the "Starnik" field, located near the village. Maidan in Dubinsky district of Rivne region on the area of 606,85 ha. occurs according to the scheme And with the use of harvesters with mechanical principle of collection. These products meet the requirements for raw materials for the production of semi-briquettes, which have been manufactured by SE "Rivnetorf" since 1969 at the Smiz Peat Factory.

Peat is a valuable organic substance that has long been used in agriculture for soil enrichment. In modern technologies of cultivation of various plants peat is widely used as a substitute for soil. Indispensable is peat in container technology for growing plants, in greenhouses, for industrial production of mushrooms. 
The record company LLC has been operating in the peat market since 2004. Within a short period of time, the company studied and implemented a quality system of peat extraction, started packing peat in piles, developed a system of supplying peat to buyers from Ukraine, began active export activities of its own products. Today, the company "Record" offers peat horse milling in piles and plastic bags.

High-quality peat is extracted from the licensed sections of the morochno-1 and morochno- 2 peat fields located in the picturesque woodland of the Dubrovytsya district, Rivne region. This deposit is characterized by stable peat quality indicators. Peat is extracted under Scheme I with the use of pneumatic harvesting harvesters.

The technology of extraction of milling peat with the use of bunker harvesting machines with pneumatic principle of collection consists of milling a layer of peat, one stirring of the obtained crumb to accelerate its drying on the surface of the map, collecting peat from the spread by air flow nozzles of the harvesting machine. The collected peat is collected in the field stacks. The stacks are placed at the ends of the cards (scale strips), as with the technology of milling peat extraction with the use of bunker harvesters with mechanical principle of collection.

The pneumatic method of collecting peat from the surface of the drying fields is carried out by suction of the milling crumb from the spreader through the nozzle into the pipeline and transporting the peatair mixture through pipelines to the cyclone, where the peat particles are separated from the mixture and deposited in the hopper of the harvesting machine.

The technological process is carried out by a set of technological equipment, which includes a milling drum, a mixing machine, a harvesting and stacking machine. The planned cycle duration in the production of milling peat for fuel in the pneumatic method of harvesting is 1 day. The number of cycles per season is 54-56.

The site on which the flowchart operations are carried out is similar to the site with the use of hopper machines with mechanical collection principle. Peat is stored in two stacks, located at opposite ends of the cards [14].

On the basis of SE "Rivnetorf" of the "Starnik" peat field, a study of peat extraction was carried out with the use of pneumatic harvesting principle. 
At present, in this peat extraction of milling peat is carried out by means of bunker harvesting machines with mechanical principle of collecting, which collect the finished products in the bunker and take it to the place of storage on the scale strips. The peat is collected directly from the rolls. The main disadvantages of this technology are the presence of the operation of rolling, cycle of work 2 days. The length of the dimensions of the site implies the size of the length of the roll so that the volume of peat in the roll is equal to the volume of the hopper of the harvesting machine. Otherwise, it will be irrational to use the performance of the harvesting machine:

- if the volume of peat in the roll is greater than the volume of the machine, the machine will not be loaded;

- If the volume of peat in the roll is greater than the volume of the hopper of the harvester, then some of the peat will remain in the roll and will interfere with the technological operations in the successor cycles.

Changing the length of the roll requires changing the width of the strip from which the peat feeds into the roll, which in turn leads to a change in the design of the roll.

On the basis of the conducted researches it is established that one of the promising ways to reduce the cycle of work up to 1 day (to increase the volumes of peat extraction) and also to exclude the operation of rolling (to reduce the staff, to reduce the costs of fuel and lubricants) is to replace the existing technology with the technology of extraction peat using bunker harvesters with pneumatic picking principle. Improving the efficiency of this method, which is an important scientific and practical task, can be ensured by the use of modern pneumatic harvesting machines.

In our opinion, the most effective for the enterprise Rivnetorf is the replacement of the MTF-44 harvester with a JIK-40DF pneumatic harvester (Fig. 3). 


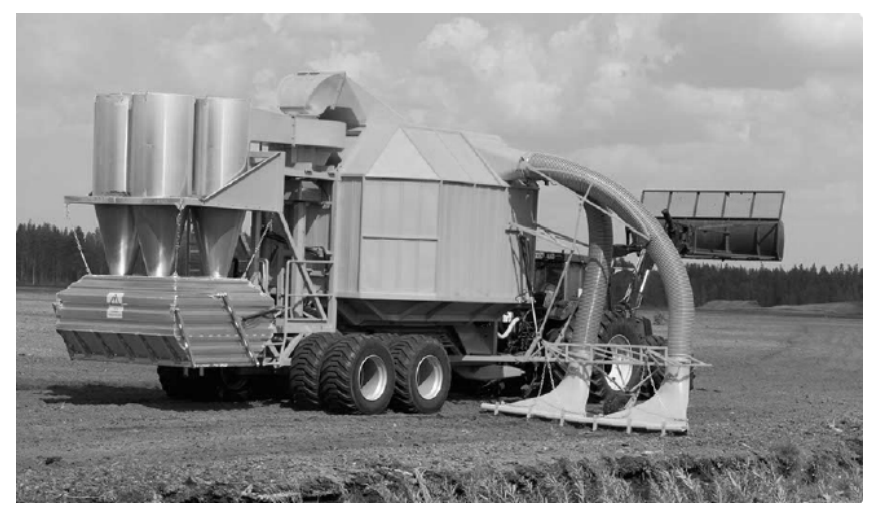

Fig. 3. JIK-40DF Harvester [17]

The pneumatic hopper is an efficient productive machine, especially when weather conditions are difficult. Pneumatic harvesters can be used at enterprises with different volumes of milling peat production [14-17].

To compare the technology of milling peat extraction with the use of bunker harvesting machines with mechanical principle of collection and technology of milling peat extraction with the use of harvesting machines with pneumatic principle of collection, the calculation of the main production and technical indicators.

The calculation of the main production and technical indicators for the technology of peat extraction with the use of pneumatic harvesting machines $[15,16]$.

1. The duration of the peat extraction season is 129 days (May 10 September 15).

2. The duration of the cycle. The planned duration of the cycle in the production of milling peat for fuel in the pneumatic method of harvesting is 1 day.

3. Number of cycles per season. During the one-day technological cycle, their number at the Starniks peat field at the Maidan section will be 54 .

4. When using pneumatic harvesting machines, the milling depth is $9 \mathrm{~mm}=0.009 \mathrm{~m}$.

5. The operating humidity of the layer milled by year for the lowland type is: first and second year - 78\%, third and subsequent $75 \%$, conditional humidity $-52 \%$. 
6. Coefficient of collection. For the third year of operation, the collection rate at a rate of $29 \%$ is 0.65 . For the second year of operation, the collection factor is reduced by 0.05 , for the first year, we reduce by 0.1 .

7. Calculation of cycle and seasonal fees by years of operation.

1. Theoretical cycle fees for the first, second, third and subsequent years

$$
\begin{gathered}
q_{c T}=\frac{10^{4} h_{f} \gamma_{e}\left(100-\omega_{e}\right)}{100-\omega_{y}} \\
q_{c T z}=\frac{10^{4} \cdot 0,009 \cdot 0,632 \cdot(100-75)}{100-52}=29,63 \mathrm{t} / \mathrm{ha} ; \\
q_{c T 2}=\frac{10^{4} \cdot 0,009 \cdot 0,692 \cdot(100-78)}{100-52}=28,55 \mathrm{t} / \mathrm{ha} ; \\
q_{c T 1}=\frac{10^{4} \cdot 0,009 \cdot 0,692 \cdot(100-78)}{100-52}=28,55 \mathrm{t} / \mathrm{ha} .
\end{gathered}
$$

2. Actual cycle fees for the first, second, third and subsequent years

$$
\begin{gathered}
q_{c f}=q_{c T} \cdot \alpha_{3} \\
q_{c f 3}=29.63 \cdot 0,65=19,26 t / h a ; \\
q_{c f 2}=28,55 \cdot 0,6=17,13 t / h a ; \\
q_{c f 1}=28,55 \cdot 0,55=15,7 t / h a .
\end{gathered}
$$

3. Theoretical seasonal fees for the first, second, third and subsequent years

$$
\begin{gathered}
q_{C T}=q_{c T} \cdot n_{c h} \\
q_{C T 3}=29,63 \cdot 54=1600,02 t / h a ; \\
q_{C T 2}=28.55 \cdot 54=1541,7 t / h a ; \\
q_{C T 2}=28.55 \cdot 54=1541,7 t / h a
\end{gathered}
$$

4. Actual seasonal fees for the first, second, third and subsequent years

$$
\begin{gathered}
q_{C f}=q_{c f} \cdot n_{c h}, \\
q_{C f 3}=19,26 \cdot 54=1040,04 t / h a ; \\
q_{C f 2}=17,13 \cdot 54=925,02 t / h a ; \\
q_{C f 1}=15,7 \cdot 54=847,8 t / h a .
\end{gathered}
$$


Similar calculations were made for current technology. Based on the obtained formula, the graphs of actual seasonal fees for the first, second and third years using current equipment and proposed (Fig. 4) [16].

The graph shows that due to the increase in cycles for the season, the actual amount of seasonal peat collection increases, almost 2 (1.88) times. This means that it is quite realistic to increase the sales of milling peat, thereby increasing the income of the enterprise.

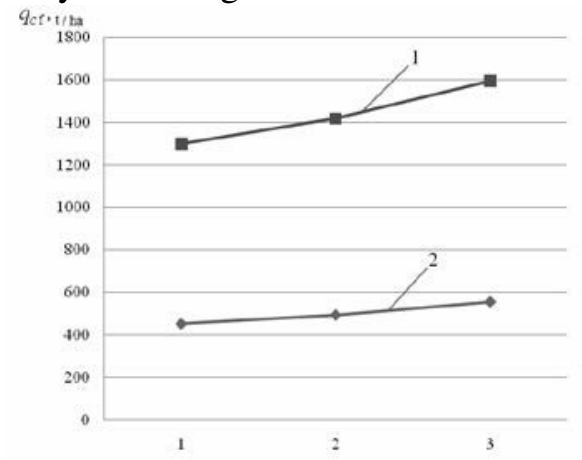

Fig. 4. Schedule of actual seasonal fees for the first, second and third years:

1 - when collecting peat with a pneumatic machine; 2 - when collecting peat with a hopper machine with mechanical principle of collection [17]

8. Seasonal program of the enterprise

$$
\begin{gathered}
P_{\text {schoc }}{ }^{\prime}=\frac{\beta \cdot P_{p}}{N_{\text {cep }}}, \\
P_{p}=19013,25 \cdot \frac{0,973 \cdot(100-86,6)}{100-52}=5164550 t . \\
P_{\text {schoc }}{ }^{\prime}=\frac{0,85 \cdot 5164,55}{20}=219490 t .
\end{gathered}
$$

9. The thickness of the layer triggered during the season is determined by the formula (6)

$$
H=\frac{q_{S F Z} \cdot\left(100-w_{y}\right) \cdot K_{B P P} \cdot K_{P G P}}{100 \cdot \gamma_{p p}\left(100-w_{p p}\right)(100-P)},
$$

where $\mathrm{q}_{\mathrm{SFZ}}$ - seasonal collection for the third and subsequent years, $\mathrm{q}_{\mathrm{SFZ}}=1040,04 \mathrm{t} / \mathrm{ha}$

$$
H=\frac{1040,01 \cdot(100-52) \cdot 0,85 \cdot 0,95}{100 \cdot 0,973 \cdot(100-86,6) \cdot(100-0)}=0,3 \mathrm{~m} .
$$


Analyzing the formula, we conclude that $0.3 \mathrm{~m}$ of peat layer can be worked during the season at the peat enterprise "Starniki", "Maidan" section, when replacing the current technological scheme with the technology of milling peat extraction with the use of bunker harvesters with pneumatic collecting principle.

The results of calculations are summarized in Table. 3 , for a visual comparison of production and technical indicators.

Table 3

Comparative characteristics of production and technical indicators [16]

\begin{tabular}{l|l|c|c|c}
\hline № & $\begin{array}{c}\text { Name of production and } \\
\text { technical indicators }\end{array}$ & $\begin{array}{c}\text { Units of } \\
\text { measurement } \\
\cdot\end{array}$ & $\begin{array}{c}\text { When mechanizing } \\
\text { harvesters }\end{array}$ & $\begin{array}{c}\text { Pneumatic } \\
\text { drive of } \\
\text { harvesting } \\
\text { machines }\end{array}$ \\
\hline 1 & Duration of the season & days & 129 & 129 \\
\hline 2 & The duration of the cycle & days & 2 & 1 \\
\hline 3 & Number of cycles & pieces & 27 & 54 \\
\hline 4 & Theoretical seasonal fees & t/ha & 853,3 & 1600,02 \\
\hline 5 & Actual seasonal fees & t/ha & 554,6 & 1040,04 \\
\hline 6 & $\begin{array}{l}\text { The thickness of the layer } \\
\text { triggered during the season }\end{array}$ & $\mathrm{m}$ & 0,2 & 0,3 \\
\hline
\end{tabular}

According to the results of Table 3, a comparative histogram (Fig. 5) of production and technical indicators was used when using pneumatic harvesting machines and using mechanical harvesting machines [16].

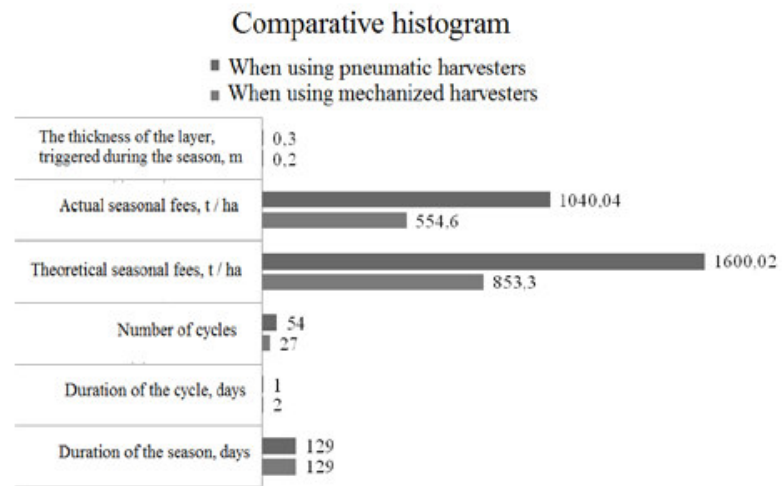

According to the results of Table 3, a comparative histogram (Fig. 5) of production and technical indicators was used when using pneumatic harvesting machines and using mechanical harvesting machines [16]. 
Having analyzed this histogram, it is established that the use of bunker harvesting machines with pneumatic principle of collecting on the "Maidan" section of the "Starnik" peat bog is expedient and promising. The proposed technology is more efficient. After all, when using bunker harvesters with mechanical principle of collection, the production and technical indicators are worse than when the technology of milling peat extraction with the use of bunker harvesters with pneumatic principle of collection. This means that it is quite realistic to increase the extraction and sale of milling peat by 1.8 times, thereby increasing the enterprise's income.

Having analyzed this histogram, it is established that the use of bunker harvesting machines with the pneumatic principle of collecting on the "Maidan" section of the "Old Man" peat bog is expedient and promising. The proposed technology is more efficient. After all, when using bunker harvesters with the mechanical principle of collection, the production and technical indicators are worse than when the technology of milling peat extraction with the use of bunker harvesters with the pneumatic principle of collection. This means that it is quite realistic to increase the extraction and sale of milling peat by 1.8 times, thus increasing the enterprise's income.

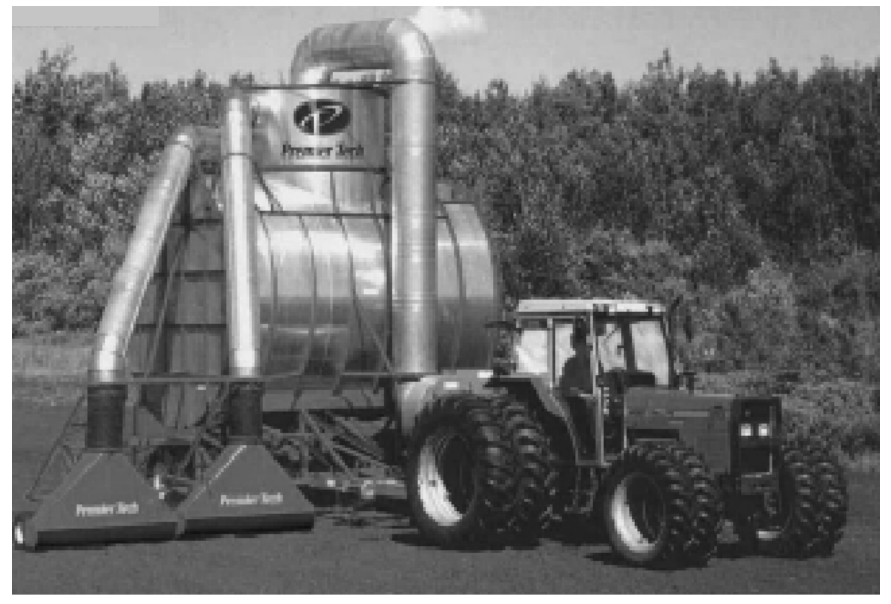

Fig. 6. Machine for vacuum peat cleaning 
It is the Canadian technique that allows to preserve the intact structure (fibrousness) of peat, thus retaining its high moisture retention capacity.

The record company LLC has been operating in the peat market since 2004. Within a short period of time, the company studied and implemented a quality system of peat extraction, started packing peat in piles, developed a system of supplying peat to buyers from Ukraine, began active export activities of its own products. Today, the company "Record" offers peat horse milling in piles and plastic bags.

Most of the peat is exported to Europe and Asia for further processing into the final product - peat mixes for growing a variety of plants. In 2010, Record launched its own substrate production line. This equipment allows every consumer in Ukraine to obtain a quality product for growing plants directly from the manufacturer. The stability of the raw material base, the experience of foreign partners, the extensive capabilities of the automatic production line of peat substrates together make it possible to present a series of European quality substrates at attractive prices.

\section{Conclusions}

Given the above, it can be noted that the rational extraction of milling peat depends not only on the reserves of deposits, but also on the technological equipment used in the technological scheme for the development of peat deposits, which in turn affects its economic feasibility of use in the peat enterprise as a whole, which directly affects the profit of the enterprise.

\section{References}

1. Moshinsky V.S., Gneushev V.A. Criteria and methodology for preliminary assessment of the ecological status of Polesie peat deposits. Journal «Problems of rational use of natural resources and sustainable development of Polesie». Proceedings of the International Scientific Conference. In two volumes. Minsk, Pp. 89-93, (2016).

2. Sushik I.V. Volyn peat industry: post-war development and current state of the industry. Scientific notes of VSPU them. M.M. Kotsyubinsky. Series: HistoryVip. 25. Pp. 152-155, (2017).

3. Mineral Resources of Ukraine [Electronic resource]. Access mode: http://minerals-ua.info/golovna/goryuchi-korisni-kopalini/. 
4. Gray M. Peat resources of Ukraine: current state, prospects of use. Economic and social geography. Scientific Notes № 1. pp. 81-85, (2012)

5. State balance of mineral resources of Ukraine as of 01.01.2008 92. Peat. K . (2008)

6. Gneushev V.A. Peat processing into fuel briquettes: Educ. manual. Exactly: NUVHP, 212 p., (2008)

7. Mineral Resources of Ukraine [Electronic resource]. Access mode: http://geoinf.kiev.ua/ publikatsiyi / shchorichnyky / mineralni-resourcesy-ukrayiny.

8. Pichugin A.V. Peat fields. -M .: Higher School, 270 p., (1967)

9. Analysis of the state of the raw material base of peat and sapropel of Ukraine in 1991-1995. Peat. 1. Analysis of the state of the raw material base of peat. Explanatory note. The state. Committee of Ukraine on Geology and Subsoil Use, Gos. information geological fund of Ukraine "Geoinform". K ,(1996)

10. Bodnaruk T.S. Use of peat and peat deposits. Part 1: NULGP Training Manual, Exactly P. 174. (2008)

11. Kucheruk M., Stryha V., Malikov V. Analysis of reserves and estimation of the scale of development of peat deposits in Rivne region. Abstracts of the Third AllUkrainian Scientific and Practical Conference of Students, Graduate Students and Young Scientists "Prospects for the development of mining and rational use of natural resources" "ZhSTU”. Pp. 60-62. (2016)

12. Kucheruk M., Strykha V., Halik O. Estimation of prospects of development of peat deposits in Rivne region. Abstracts of the Third All-Ukrainian Scientific and Practical Conference of Students, Graduate Students and Young Scientists "Prospects for the development of mining and rational use of natural resources" "ZhSTU”. 2016 Pp. 74-76.

13. Gneushev V.A. Formation and development of technogenic fields. Educ. manual. - Rivne: Volyn Charms, 152 p., (2013)

14. Malanchuk Z.R., Gavrish V.S., Strikha V.A., Kirichik I.M. Open pit mining technologies. NUHPP Training Manual. Exactly Pp. 255-277. (2013) (2010)

15. Gneushev V.A. Peat briquetting. Monograph. - Exactly: NSUPP, 167 p.,

16. Kucheruk M.O. Master's thesis "Investigation of the technological process of peat extraction on the section" Maidan "of the Peat field" Starniki "supervisor: Ph.D. Pp. 61-72.

17. Peat machines. Equipment for extraction and processing of peat. [Electronic resource]. Access mode: URL: https://peatmachine.at.ua/index/pnevmaticheskij_kombajn_jik_40df/0-25 